Медицинска школа, Пожаревац професорка српског језика и

књижевности

tinapostic6@gmail.com

\title{
ИНТЕРДИСЦИПЛИНАРНИ ПРИСТУП ПИСМЕНИМ САСТАВИМА У НАСТАВИ ЈЕЗИЧКЕ КУЛТУРЕ
}

\begin{abstract}
АПСТРАКТ
С обзиром на изузетан значај који у циљу подизања нивоа језичке културе има писмено изражавање, у овом раду пажња ће бити усмерена на интердисциплинарни приступ писменом саставу као најважнијем и основном начину којим се ова настава спроводи и проверава. Иако настава културе писменог изражавања има законски регулисане циљеве, у пракси је примећено да њиховом достизању постојећи методички приступи не доприносе на задовољавајућ начин. У настави писменог изражавања примена приступа који се користе у реторици, анализи дискурса и лингвистици текста, могла би допринети оспособљавању ученика да различите врсте текстова уме да разуме и произведе у складу са потребама савременог живота и друштва.
\end{abstract}

Кључне речи: интердисциплинарност, методички приступи, писмени састав, текст

\section{INTERDISCIPLINARY APPROACH TO WRITTEN ESSAYS IN TEACHING LANGUAGE CULTURE}

\begin{abstract}
Due to the great importance of written expression in raising the level of language culture, in this paper the attention will be focused on interdisciplinary approaches to writing as a part of the most important and basic way in which these classes are carried out and assessed. Although teaching the culture of written expression has legally regulated goals, in practice it was observed that the existing methodological approaches do not contribute satisfactorily to their achievement. In teaching written expression the implementation of approaches used in rhetoric, discourse analysis and text linguistics could contribute to the training of students to understand and
\end{abstract}


produce different types of texts in accordance with the needs of modern life and society.

Keywords: interdisciplinarity, methodical approaches, written composition, text.

\section{1. УВОД}

Интензиван научни и технолошки развој, прелазак у информатичко друштво и експанзија нових сазнања у свим сферама, наметнули су нове захтеве и у образовању. Васпитно-образовни циљеви треба да буду усклађени са потребама савременог времена.

У школском просецу настава матерњег језика има веома значајно место, не само због специфичних циљева и задатака које овај предмет има, већ и зато што код ученика развија васпитне вредности, знања и вештине које ће моћи да користе у даљем образовању, професионалном раду и свакодневном животу. Стога, чини се, ниједан други предмет нема толику васпитну и образовну вредност као што је настава матерњег језика.

Искуства из школске праксе и резултати досадашњих испитивања, међутим, указују на незадовољавајући ниво језичке културе код ученика. Традиционалан приступ настави језичке културе не доноси више жељене резултате и о ниској језичкој писмености наших ђака говоре многа истраживања и студије (Шипка 1959, Марковић 1959, Салонски 1959, Павловић 1990, Брборић 2004, Зељић 2004, Драгићевић 2006, Јањић 2008, Стевановић 2011).

Више формалистичкој него функционалној и подстицајној настави језичке културе, поред малог броја часова и неадекватних садржаја, због застарелих програма, недостају и савремене методе и приступи. Приступ писменом саставу треба бити интердисциплинаран, да представља интеграцију знања и теоријских приступа из разних дисциплина.

Савремене технике и методе, преузете из сродних дисциплина, могу помоћи и наставницима и ученицима да се одреде у односу на степен савладавања одређених знања, вештина и показивања ученичких способности, које су јасно дефинисане и стандардима ${ }^{1}$. Стандарди, као

${ }^{1}$ Стандарди за крај првог циклуса обавезног образовања објављени су у Правилнику о образовним стандардима за крај првог ииклуса обавезног образовања за предмете српски 116 језик, математика и природа и друштво 7. јуна 2011. у Просветном гласнику РС, бр. 5, а 
описи ученичких постигнућа, надређени су садржајима школских програма и њима је описано шта ученици требају да знају, умеју и могу, и шта наставник треба да уради како би им то омогућио. Наставник треба да припрема програм рада тако да уважава стандарде постигнућа и да повеже програмске садржаје са одређеним стандардима.

Предмет истраживања овог рада су методички приступи писменом саставу као најважнијем и основном начину којим се настава писменог изражавања спроводи и проверава. Најпре ће бити указано на сам значај језичке културе, њен положај у пракси и законским регулативама, на текстуалне карактеристике писменог састава, а затим на приступе, стратегије и методе из сродних дисциплина: реторике, анализе дискурса и лингвистике текста, које се могу применити и на наставу учења вештине писања писменог састава, што представља и циљ овог рада.

\section{2. ЗНАЧАЈ ЈЕЗИЧКЕ КУЛТУРЕ}

„У језику су присутне све тековине људског духа, све што је човјек открио, спознао и створио. Језична култура најпотпуније обиљежава ступањ културе једног народа. У културном свијету брига о развијању језичне кулуре не очитује се само у професионалним круговима. Сваки културни појединац води бригу о својој језичној култури. Осјетљивост према језику као средству изражавања карактеризира култивирану личност без обзира на њезину стручну усмјереност. Већ су стари Грци језичну културу узимали као вриједносну категорију у просуђивању личности”. (Росандић 1973: 113)

У основној и средњој школи српски језик се изучава заједно са књижевношћу, а спој ова два подручја чине језичку културу. Према осталим подручјима наставе: наставом граматике и правописа, наставом стилистике и наставом књижевности, настава језичке културе стоји у комплементарном односу, а и с осталим предметима је у тесној вези.

Прилике за системско и организовано учење језичке културе након завршене средње школе су ограничене, јер је мало факултета на којима се такав предмет изучава. С обзиром на то да велики број ученика не наставља даље школовање, средња школа представља место где се језичка култура

стандарди за крај средњег општег и стручног образовања објављени су у Правилнику о општим стандардима постигнућа за крај општег средњег образовања и средњег стручног образовања у Службеном гласнику РС, бр. 117/2013. 
највише учи и развија, и управо током школовања ученицима треба омогућити адекватно образовање из ове области и дисциплина којима је блиска.

\section{1. Законске регулативе и језичка култура}

Савремена настава матерњег језика има задатак да ученика, по завршеном средњем образовању, оспособи да: влада усменом и писаном комуникацијом, саставља логичан и стилски складан говорени и писани текст који је добро структуриран и стилски складан, прецизно износећи идеје, владајући основним писаним жанровима потребним за школовање и учешће у друштвеном животу, а на напредном нивоу, ученик треба да пише и стручне текстове на теме из језика и књижевности.

Сагледавањем целокупне наставе предмета српски језик и књижевност, у основној и средњој школи, уочава се, када је област језичке културе у питању, да постоје извесне препреке у достизању законски регулисаних циљева које ова област има. Те препреке се првенствено тичу метода и приступа којима се настава спроводи, али и фонда часова и програмских садржаја.

У основним школама наставним планом предвиђен је довољан број часова и за језичку културу и за наставу језика, као и часови за увежбавање пређених садржаја, док је у средњим школама настава језичке културе и граматике дефицитарна и занемарена на уштрб наставе књижевности ${ }^{2}$ (Петровачки 2008: 10).

О неједнакој заступљености подручја књижевности, језика и језичке културе у настави матерњег језика указивано је и раније у најзначајнијој методичкој литератури ${ }^{3}$, као и у запажањима еминентних стручњака који су се бавили српским језиком и наставом (А. Белић, Д. Живковић, Р. Димитријевић, И. Мамузић, М. С. Лаловић, П. Илић и др). Како би се у извесној мери овакво стање у настави српског језика и књижевности, у средњој школи, поправило, предлагано је да се овај предмет раздвоји на два

\footnotetext{
${ }^{2}$ Настава књижевности обухвата $60 \%$ часова, док је за наставу језика и културе изражавања издвојено $40 \%$ часова. У оквиру тог фонда планирани садржаји се обрађују са $70 \%$ часова. Осталих 30\% часова предвиђено је за понављање, утврђивање, вежбање и систематизовање програма (Службени гласник РС, бр. 72/09 и 52/11).

${ }^{3}$ Методика наставе српског језика Милије Николића и Методика књижевног одгоја и образовања Драгутина Росандића и др.
} 
предмета: наставу језика и наставу књижевности. Методичари се са таквим предлогом нису сложили, истичићу као главни аргумент дубоко јединство и повезаност језика и књижевности.

Према плану и програму ${ }^{4}$ удео часова језичке културе у средњој школи износи највише: 35, 19,4\% (у III разреду гимназија - језичког смера), а најмање: 6 часова, 10\% (у III разреду, трогодишњих стручних школа), тако да просечан планирани број часова културе изражавања у средњим школама износи: 15,26\%.

Ради унапређења квалитета образовања стандарди постигнућа ученика постали су обавезујући за примену од 2010. године. За матерњи језик ови стандарди су постали обавезујући у основној школи од 2011, а од 2014. и у средњој школи. Стандарди постигнућа ученика - образовни стандарди за крај обавезног и средњег образовања значајна су новина у нашем образовном систему и наставници треба да припреме облик рада тако да, поред наставног плана и програма ${ }^{5}$, уважавају и стандарде постигнућа 6 . С обзиром на то да наши наставни програми још увек не дају смерницу о исходима учења, наставници сами морају пронаћи везу између стандарда и постојећих садржаја планираних наставним програмом. То је још један од

\footnotetext{
${ }^{4}$ Правилник о плану и програму образовања и васпитања за заједничке предмете у стручним и уметничким школама (Службени гласник СРС - Просветни гласник, бр. 6/90 и Просветни гласник, бр. 4/91 7/93, 17/93, 1/94, 2/94 2/95, 3/95, 8/95, 5/96, 2/02, 5/03, 10/03, 24/04, 3/05, 6/05, 11/05, 6/06, 12/06, 8/08, 1/09, 3/09, 10/09, 5/10 і 8/10), Правилник о изменама правилника о плану и програму образовања и васпитања за заједничке предмете у стручним и уметничким школама (Просветни гласник, бр. 11/13 од 28. 06. 2013. године) и Правилник о наставном плану и програму за гимназију (Службени гласник СРС - Просветни гласник, бр. 5/90 и Просветни гласник, бр. 3/91, 3/92, 17/93, 2/94, 2/95, 8/95, 23/97, 2/02, 5/03, 10/03, 11/04, 18/04, 24/04, 3/05, 11/05, 2/06, 6/06, 12/06, 17/06, 1/08, 8/08, 1/09, 3/09, 10/09, 5/10, 7/11 и 4/13).

${ }^{5}$ Правилник о плану и програму образовања и васпитања за заједничке предмете у стручним и уметничким школама (Службени гласник СРС - Просветни гласник, бр. 6/90 и Просветни гласник, бр. 4/91 7/93, 17/93, 1/94, 2/94 2/95, 3/95, 8/95, 5/96, 2/02, 5/03, 10/03, 24/04, 3/05, 6/05, 11/05, 6/06, 12/06, 8/08, 1/09, 3/09, 10/09, 5/10 і 8/10), Правилник о изменама правилника о плану и програму образовања и васпитања за заједничке предмете у стручним и уметничким школама (Просветни гласник, бр. 11/13 од 28. 06. 2013. године) и Правилник о наставном плану и програму за гимназију (Службени гласник СРС - Просветни гласник, бр. 5/90 и Просветни гласник, бр. 3/91, 3/92, 17/93, 2/94, 2/95, 8/95, 23/97, 2/02, 5/03, 10/03, 11/04, 18/04, 24/04, 3/05, 11/05, 2/06, 6/06, 12/06, 17/06, 1/08, 8/08, 1/09, 3/09, 10/09, 5/10, 7/11 и 4/13).

${ }^{6}$ Правилник о општим стандардима постигнућа за крај општег средњег образовања и средњег стручног образовања у делу општеобразовних предмета (Службени гласник РС, бр. 117/2013).
} 
разлога због којег треба у настави језичке културе осавременити приступе и методе и теоријску потпору потражити у сродним дисциплинама.

Анализом законских регулатива долазимо до закључка да је за наставу језичке културе у средњој школи предвиђен мали број часова, да се настава културе писменог изражавања реализује према задацима који нису сасвим прилагођени данашњем времену, јер средњошколци наставу језичке културе похађају према наставним програмима који су написани у последњој деценији прошлог века (1991. године), нити су у складу са обавезујућим стандардима постигнућа.

\section{3. ПИСМЕНИ САСТАВ И ЮЕГОВО МЕСТО У НАСТАВИ ЈЕЗИЧКЕ КУЛТУРЕ}

Писмени састави у настави језичке културе су од фундаменталног значаја, јер представљају основно средство помоћу којег се ученици оспособљавају да самостално стварају текстове и развијају своју писменост. Њихова израда је донекле ограничена, постоји слобода при одабиру грађе и садржаја, али је она подређена и усклађена са темом коју је задао наставник. Иако је самосталност у извесној мери ограничена, писање састава је стваралачки чин који настаје у околностима веома сличним правом писању. То им омогућава савладавање и усвајање општих елемената писмености на којима се темеље сви облици писане комуникације. Писмене саставе ученици израђују у школи и код куће, а четири пута у току школске године писани састави добијају облик писмених задатака и оцењују се.

„Док пише састав, ученик одабира, вреднује и распоређује чињенице и језичке знаке, примењује пригодна гледишта и критерије, репродукује и ствара, а то су радње које су неопходне и за писање пословног извештаја, радног пројекта, писма, молбе, стручног рада, расправе, новинске вести, репортаже и било кога другог наменског текста" (Николић 1983: 12). Зато писмени састави, којима се провера ученичко знање о писању, повремено треба да буду у облику и са функцијом: писма, вести, извештаја, интервјуа и др., јер је крајњи циљ наставе писаног изражавања добра писменост и способност састављања текстова потребних за школовање и свакодневну комуникацију, а не неговање литерарно-емоционалног стила и стварање писаца (Николић 1983: 13, Стевановић 1988: 27). 


\section{1. Писмени састав и стање у пракси}

Подручје језичке културе развија код ученика културу говора и писања. Писани текстови представљају основу за сваку културу и значајнији су од усмених јер их можемо преносити, без ограничења, кроз простор и време.

У пракси наставнике више занима писмени састав као крајњи продукт писања, занемарују чињеницу да је писање процес који се одвија у више фаза (Flower \& Hayes 1981). Продукт писања се узима као примарни циљ и велика пажња се поклања техничком изгледу рада, граматичким грешкама и правопису, а мање се обраћа пажња на сам процес настанка и израду рада, уз потпуно занемаривање чињенице да ученици углавном не знају како да кроз тај троцес прођу. Стратегије планирања, израде нацрта и исправљања написаног текста су кључне стратегије у писању и у директној су вези са квалитетом писаног рада (Rosenberg 1989), па стога, у моделирању процеса учења вештине писања, треба поћи од интеракцијског или процесног приступа поучавању писања, уместо традиционалног коме је производ написаног једино важан (Nikčević Milković 2008).

Ученицима се често ускраћује прилика да се упознају и са другим жанровима и стиловима којима писане поруке могу бити израђене, јер је најчешћи облик писменог састава есеј на слободну тему или тему из градива.

Такво стање је довело до уверења да ученици сами треба да развијају способност писања и да на квалитет писмених састава пресудно утичу таленат и инспирација. Није им довољно познат циљ наставе писменог изражавања и немају јасан увид у сопствено писање. Самовредновање процеса писања може имати веома значајну улогу у стицању потребних знања за израду писмених састава, као и развијање саморегулацијских вештина које усмеравају исправку рада на свим нивоима текста, односно писменог састава (Nikčević Milković 2010).

Недостатак стручне литературе која би културу писменог изражавања третирала са једног новог, савременог становишта, као и недостатак уџбеника ${ }^{7}$ из језичке културе за средњошколце, такође неповољно утичу на стање у настави.

\footnotetext{
${ }^{7}$ На основу Извода из регистра одобрених уџбеника за школску 2016/2017. годину на сајту МПНТР http://www.mpn.gov.rs/udzbenici/
} 
Приступ настави културе писменог изражавања мора бити функционалан и интердисциплинаран. Теоријску потпору култури писменог изражавања не чини само функционална граматика, стилистика и ортографија, већ се она ослања и на друге лингвистичке дисциплине, као и на психологију, логику, реторику и др. Ту ће се наћи облици, методе, средства и знања о ученичким психофизичким потребама и могућностима, мотивацији, аспирацијама, техникама, организованим и ефикасним системима вежби које поспешују развијање способности писменог изражавања.

\section{2. Врсте писмених састава}

Врсту и облике писмених састава је тешко систематизовати. У литератури не постоји јединствен став у погледу критеријума и врсти. Различити аутори полазе од различитих критеријума за утврђивање поделе, али ниједна подела није коначна, нити је самој себи довољна. Отуда се намеће потреба научне класификације писмених састава у наставном поцесу.

Прегледом литературе иманентних стручњака на пољу лингвистике, методике наставе и теорије књижевности уочене су неке класификације и подела текстова, односно писмених састава и запажамо да су критеријуми за класификацију установљени на основу функције, структуре и тематике.

Стога се писмени састави јављају у облику: приповедања, описивања, извештавања и расправљања. Сваки од ових облика обухвата низ посебних тематских кругова и грана се у специјалне облике и врсте (Николић 1983: 7-10).

Детерминисање врсте текста је од великог значаја и за продукцију и за рецепцију текста. Тип текста је смерница за израду и процесуирање текстова. Текстове стварамо са одређеном намером: да утичемо њиме на онога коме је намењен, да му нешто поручимо, изјавимо и др. Уколико о теми текста који израђујемо или читамо имамо добро предзнање, његова израда или разумевање је брже и подробније. Исто тако, лакше и функционалније можемо створити и разумети текст уколико знамо којој врсти припада, односно познајемо његову структуру и језичка средства којима се остварује његова комуникативна намера. 
3.3. Дефинисање појма писмени састав и сродност са појмом текст

У свом шестом значењу у РСЈ, лексема састав дефинисана је као писани рад, обично школски, односно уопште сачињен текст. Атрибут писмени, поред тога што у свом значењу даје податак о писмености и граматичкој исправности, у свом трећем значењу, у РСЈ, у именичкој служби, означава и задатак или испит у школи, на факултету и сл. који се ради, односно обавља у писаној форми. Писмени састави су, дакле, текстови који се израђују у писаној форми, граматички су исправни и представљају основни облик изражавања и обуке у настави писменог изражавања.

Писмени састави, као текстови које ученици самостално стварају и који имају употребну вредност у друштвеној пракси (Николић 1983), имају и све оне карактеристике које и текст има. Стога, методологија израде и вредновања писмених састава подразумева да се њима приступи као у дисциплинама које за предмет истраживања имају текст.

Појам текста дефинисан је на различите начине, од тога да је текст исказ од једне речи, па до тога да се само вишереченични исказ у писаном облику може сматрати текстом (Павловић, Шарић 2012). Под текстом се подразумева сваки низ реченица, било које дужине, који сачињава јединствену целину. Он може бити говорени или писани, прозни или у стиховима, дијалошки или монолошки (Halliday, Hasan 1976). Текст, такође, није само језики феномен, већ је он, као што истичу Богранд и Дреслер (1991) и комуникацијски догађај.

Текст има своју микроструктуру, чисто лингвистички аспект, који најчешће укључује речи, фразе, клаузе и реченице, и макроструктуру, подразумева оно што је у тексту, а изван је нивоа реченице: тематска и организациона структура текста која зависи од његове дискурсне структуре, односно припадности неком жанру.

Сваки текст и књижевни и некњижевни настаје као резултат језичке креативности (способности) говорника/писца да ограниченим језичким средствима који су му на располагању одговори на конкретну говорну ситуацију (Павловић, Шарић 2012). Текст мора испунити седам стандарда и 
на тај начин стиче своју текстуалност ${ }^{8}$, уколико један стандард није испуњен, сматра се да текст није комунукацијски догађај.

Конкретан текст се увек јавља као пример одрђене врсте текста. Класификација текстова се одређује према функцији коју текст има, и управо та функција дефинише целу класу текстова, а појединачне врсте, унутар једне класе, могу се разликовати помоћу). категорија: комуникацијски облик, подручје деловања, тема текста, облик развијања теме и др. (Brinker 1985).

\section{4. НОВИ ИНТЕРДИСЦИПЛИНАРНИ ПРИСТУП ПИСМЕНИМ САСТАВИМА}

Нови приступ настави писменог изражавања подразумева разрађен систем техника и савремене методе којима ћемо код ученика развити способност да одређене текстове произведе и разуме у складу са савременим потребама наставе и друштва. Пажњу треба усмерити на упознавање ученика са свим фазама у изради једног састава и свим његовим структурним елементима. Нови приступ, такође, нуди и јасне критеријуме вредновања и оцењивања.

Иако је примарни циљ наставе писменог изражавања писање као продукт, савремени приступ треба бити усмерен и на сам процес који се одвија у току израде састава. Важно је да наставници, током школовања, науче ученике како настаје текст - да им омогуће пролазак кроз процес, тј. фазе стварања текста, сходно њиховом узрасту и могућностима, и да ту вештину развијају из разреда у разред, како би то знање некад у свакодневном живот могли да примене. Није довољно само задати тему и оценити рад. Савремени приступ оцењивању уважава и сам процес учениковог учења и стварања, а не само резултат рада. Задатак наставника је да ученика оспособи како да нешто уради, а не само да провери шта је урадио (Глишић, Илић и др. 2013).

${ }^{8}$ Под текстуалношћу се подразумева могућност да се језичким средствима изгради текст. 
4.1. Могућност примена приступа из других језичких дисциплина у настави писменог изражавања

Теоријски уопштена искуства о тексту, његовој организацији и структури, предмет су истраживања различитих дисциплина: анализе дискурса, лингвистике текста, контрастивне лингвистике, реторике, стилистике, теорије жанрова, социологије, антропологије, психологије, књижевности, семиотике, информатике и др, али и методике наставе писаног изражавања, јер су писмени састави заправо текстови и представљају припремне облике којима ученици усавршавају своју писменост. Међу овим дисциплинама, њиховим приступима тексту, могу се потражити методе којима би се настава писаног изражавања осавременила и прилагодила потребама савременог друштва.

У овом раду осврнућемо се на методичке приступе тексту који се примењују у реторици, анализи дискурса и лингвистици текста.

\section{2. Реторика}

Настанак реторике као посебне дисциплине везује се за доба око V века пре нове ере и амбијент хеленских демократских полиса, мада можемо рећи да је говорништво као практична вештина старо колико и људска цивилизација. Реторика означава говорничку вештину, тј. представља науку о принципима правилног и убедљивог говорења. У грчкој филозофији реторика је чинила део логике, а основали су је софисти. У српском језику термин реторика употребљава се равноправно са домаћим речима беседништво и говорништво.

Реторика може бити од велике помоћи при писању. Она има разрађен систем прикупљања, одабирања, сређивања и начине уобличавања материјала, поседује збир поступака и критеријума који писцима могу олакшати у композиционом процесу, као и пегршт изражајних средстава којима могу своје текстове прилагодити разним ситуацијама (Јелачић Србуљ 2005).

Наставним планом и програмом, усвајање знања о есеју, као облику писменог изражавања, предвиђено је тек за четврти разред гимназије и средње стручне школе, иако се са припремама за писање есеја почиње и знатно раније, још у старијим разредима основне школе (Живковић 2013). Стандарди ученичких постигнућа предвиђају оспособљавање ученика за 
састављање аргументативног текста на теме из књижевности, језика и културе, а једно од основних обележја есеја је управо чврста аргументација.

Есејистичко изражавање је подврста писменог састава (Живковић 2013) и есеј има много заједничких тачака са беседом: карактерише их „краткоћа и језгровитост, а форма увек следи облик мисли” (Јелачић Србуљ 2007).

При изради есеја или неког другог аргументативног текста аргументација, односно доказивање, је важан услов уверљивости. Реторика прави разлику између етичког и аподиктичког уверавања. Етичко се темељи на емоционалном, а аподиктичко на логичком аргументовању.

Етичко уверавање. У процесу етичког уверавања треба користити примере, изреке, општа места (Јелачић Србуљ 2005: 131).

Примери уливају поверење, служе као сведоци, а најуверљивија метода је изношење личног доживљаја као примера

Изрека изриче једну истину, животну мудрост једног народа, једне културе. Управо својом општошћу помаже ономе ко чита или слуша да препозна у том општем важењу оно појединачно, индивидуално, што је и сам од раније спознао.

Onште место је унапред припремљена формулација коју говорник користи ради попуњавања евентуалне празнине у свом говору. Опште место можемо дефинисати као схему која се може применити на различите аргументе, или правило уз помоћ којег се ствара ентимем. Места могу бити „ужа” и „шира”. Ужа места су она која се односе на посебне садржаје и могу се применити само у одређеним контекстима. То су општеприхваћене истине и мишљења, и као такве често чине премисе ентимема, које могу бити изостављене управо зато што се подразумевају. Аристотел наводи пример ужег места: „слава се састоји у томе да нас сви цене” (Аристотел: 1361).

Шира општа места су она која се тичу само формалне структуре, па се могу искористити у свакој врсти говора. Представљају уопштена правила која важе за различите аргументе, односно применљива су у свим контекстима. Такво место је такозвано „место супротности”. Оно је примењено у следећем примеру: „Добро је живети у миру јер рат доноси нecpeћe".

Аподиктичко уверавање. Представља логичку аргументацију која се

примарно базира на доказима. Доказивање са становишта логике може 
имати форму индуктивног (од појединачног ка општем, када се из особина појединачних случајева изводи закључак који важи за све друге случајеве) или дедуктивног (од општег ка појединачном). Дедуктивни облици који се најчешће користе јесу силогизам (када се из две премисе изводи закључак), ентимем (скраћени силогизам, када се закључак изводи из једне премисе док се друга подразумева) и дилема (извођење закључка из две премисе које се међусобно искључују). Ваљаност аподиктичног уверавања зависи од избора логичких судова на које се оно ослања.

\section{3. Анализа дискурса}

Анализа дискурса је интердисциплинарна област која се бави језиком, али не језиком као системом, већ његовом реалном употребом, у спрези са контекстом и невербалним елементима језичке комуникације. При томе, проучава језичке и комуникацијске целине веће од реченице. С обзиром на то да је приступ изучавања употребе већих језичких целина, с вођењем рачуна о контексту, предмет и других научних дисциплина (психологија, социологија, филозофија, антропологија) или дисциплина које су се већ током последњих 40 година "удружиле" са лингвистиком (психолингвистика, социолингвистика, антрополошка лингвистика), анализа дискурса представља веома хетерогено подручје у оквиру кога постоји разноврсност истраживачких циљева, теорија и метода (Пешић 1997).

Неке приступе и методе који се користе у анализи дискурса можемо применити и на језичку културу писменог изражавања.

Граматика приче. Предмет проучавања овог приступа су приче (наративи) као специфичан тип дискурса везан за приповедање, уједно, и први дискурсни жанр који је био анализиран (Johanson 2001)9. Циљ приступа је утврдити опште структуралне правилности приче: да се одреде структуралне јединице приче (story units) и систем правила који одређује канонички редослед јединица и услове под којима он може бити промењен. Према заступницима овог приступа, основне јединице приче су: сетинг (увођење ликова или протагониста приче, као и опис просторног и

\footnotetext{
9 Опширније о лингвистичкој структури наратива и његовој когнитивној, социјалној и психолошкој функцији у Barbara Johnstone, "Discourse analysis and narrative" published in Deborah Schffrin, Deborah Tannen \& Heidi E. Hamilton. Handbook of discourse analysis, Malden: Blackwell Publisher, 2004: 635-649.
} 
временског контекста у коме се прича дешава), тема (фокус приче из кога следи заплет), заплет (састављен из једне или већег броја епизода које садрже иницијални догађај и реакције протагониста на њега) и расплет или разрешење и наведени су редоследом који, за заступнике овог приступа, представља “граматичка” правила њиховог комбиновања (Mandler 1983).

У настави писменог изражавања описани приступ може бити од користи при структурирању текстова којима желимо да испричамо шта се догодило, приповедачких, наративних текстова којима се ученицима, поред стицања когнитивних и лингвистичких способности, омогућава и лакша социјализација, а и већа школска постигнућа (Johanson 2004).

Кохезија текста. Бави се начином на који су површинске компоненте текста, тј. стварне речи које чујемо или видимо, међусобно повезане. Захваљујући кохезивности, текст представља целину. Нарушавање кохезивности отежава или онемогућава разумевање текста, па она представља један од општих стандарда текстуалности (Beaugrande, Dressler 1981).

У оквиру анализе дискурса систематизован је и детаљно описан богат репертоар језичких средстава којима се остварује кохезивност: референција, елипса, конјукција и лексичка кохезија (Halliday, Hasan 1976).

У настави језичке културе ученике треба упознати са кохезијом текста при вежбању писања одељака у писменом задатку, нарочито пасуса. Једна мисао треба бити развијена у једном пасусу, а сви пасуси треба да се уклопе у ширу целину. При вредновању и оцењивању садржине писаних састава кохезивност треба бити један од водећих критеријума.

Дискурс новинских иланака. У оквиру општих стандарда постигнућа за крај средњег образовања, ученик на напредном нивоу треба да уме да композиционо и логички пише новински чланак.

Ван Дијк (1988а) нуди оквир анализе новинских чланака. Његово основно полазиште је да се један текст може посматрати са нивоа микроструктуре и макроструктуре. Макроструктуре се дефинишу на основу значења реченица у тексту уз помоћ низа правила као што су избор, генерализација и конструкција. Наведена правила називају се макроправила и она су нам потребна ради редуцирања информација, што је неопходно у креирању једног новинског текста. Ово се одвија на три различита начина - брисањем, генерализацијом и конструкцијом (Van Dijk 1988б: 32). Под брисањем подразумевамо избацивање информација из 
текста које више нису важне за остатак текста, као што су неки неважни детаљи. Генерализација подразумева замењивање низа исказа једном генерализацијом. На пример, уместо набрајања разних врста опреме у канцеларији, можемо рећи да имамо одговарајућу канцеларијску опрему. Најзад, конструкција подразумева замену низа исказа који означавају уобичајене услове, компоненте или последице неког чина или догађаја једним макроисказом који означава тај чин или догађај као једну целину. На пример, одлазак на аеродром, чекирање, улазак у авион, лет, слетање, итд. могу се сумирати макроисказом „Ишао сам авионом у...”. На овај начин конструишемо цео догађај из његових саставних делова. Брисање, генерализација и конструкција представљају три главна макроправила која своде информације из текста на његове теме. Ово је посебно битно када из новинског текста настаје лид и наслов.

Код макроструктура, генерално говорећи, најмање независне значењске јединице језика јесу искази. Они се јављају у облику простих реченица или клауза. Сложена реченица, с друге стране, може садржати више исказа. Ови искази користе се да означе чињенице. Може се рећи да су макроструктуре организовани скупови исказа, који се могу назвати макроискази и да свака тема текста може да се представи као један макроисказ. Текст се, међутим, најчешће састоји од више таквих макроисказа, који представљају горе поменуте функционалне целине. Шема једног новинског чланка може се представити на следећи начин:

- наслов,

- лид (сумирање главног догађаја),

- главни догађај (разрада догађаја поменутог у лиду),

- позадина догађаја (ко, како, где и кад),

- вербални коментар (најважнији учесници у догађају),

- евалуација (ставови, очекивања и евалуација догађаја од стране новинара),

- резултати радње (зашто је догађај битан, озбиљност његових последица).

Сваки од наведених седам делова представља одређену функционалну целину, састављену на основу теме или намере која се њоме преноси. Писање новинског чланка један је од стандарда на напредном нивоу. 


\section{4. Лингвистика текста}

Лингвистика текста почела је да се развија 70-их година 20. века у Аустрији, Немачкој и Холандији. Године 1981. објављена је књига R. De Beaugrandea i W. Dresslera Introduction to Text Linguistics, у којој ова два аутора одлучују да приступе тексту с аспекта његове употребе, што подразумева неопходност идентификације дискурса у којем се он остварује. Текстови се међусобно разликују по својој припадности, по врсти којој припадају, те је задатак науке о тексту да утврди која су заједничка, а која различита обележја појединих текстова и текстних врста. Лингвистика текста се бави следећим питањима: како се производе и перцепирају текстови, како се користе у контексту, које критеријуме текстови морају испунити и које су функције текстова у људској интеракцији.

Текст је комуникацијски догађај, а не само језички феномен, и текстуалност неког текста се може одредити само на основу стандарда текстуалности, иначе се неће сматратрати комуникативним.

Први стандард: кохезија - представља начин на који су површинске компоненте текста, тј. стварне речи које чујемо или видимо, међусобно повезане.

Други стандард: кохеренција - на површинском нивоу структуре текст карактерише кохезија, скуп језичких феномена који повезују елементе текста међусобно. Кохезија, међутим, није довољна да обезбеди тексту кохеренцију. Кохеренција подразумева когнитивно повезивање прочитаног са представама читаоца, његовим претходним знањима, очекивањима и стварање једне нове менталне структуре, за коју је текст био само повод. Кохезија и јесте заправо стратегија коју писац користи да би помогао читаоцу у грађењу кохеренције текста, без обзира на разноликост жанрова и мноштво типова текста, између онога ко је текст сачинио и онога ко тај текст чита интеракција постоји: само су видови и манифестације те интеракције различити (Ђоровић, 2008).

Трећи стандард: интенционалност - подразумева да је став аутора текста такав да жели створити кохезиван и кохерентан текст који ће испунити његове намере и постићи циљ.

Четврти стандард: прихватљивост - подразумева став примаоца текста, он очекује кохезиван и кохерентан текст који је за њега користан или релевантан. 
Пети стандард: информативност - појам који одређује до које је мере неки текст нов или неочекиван у односу на примаоца текста. Појам се односи првенствено на садржај, јер садржај у било ком језику треба пре свега бити информативан, али се може односити и на форму у којој је садржај реализован. Текстови вишег нивоа информативности су захтевнији што се тиче процесирања, али се тиме може остварити већа мотивисаност читаоца, активнији приступ тексту или одређени уметнички ефекат.

Шести стандард: ситуативност - значи релевантност текста за комуникацијску ситуацију. Сваки текст, поред тога што поседује неке опште карактеристике има и специфичне одлике које произилазе из конкретног контекста - коме је текст намењен, за коју сврху, и у каквим се условима користи. Добар текст је увек прилагођен постојећој ситуацији, тј. комуникационом контексту.

Седми стандард: интертекстуалност - подразумева зависност продукције и рецепције датог текста од знања стеченог кроз претходно искуство са различитим врстама текстова, за шта аутори користе термин медијација. Највећи степен медијације у вези је са постојањем одређених типова текстова (врста, жанрова). У том случају, процес медијације је најрелевантнији будући да се конкретан текст разуме на основу асимилације у постојећу структуру знања о томе шта садржи и како је организован дати тип текста.

Сам процес писања треба да се одвија у неколико фаза. Стратегија израде писаног састава подразумева фазу планирања, писања и ревизије, што је један од услова добре писмености и успешне израде писаних састава. Стандарди текстуалности могу бити један од основних критеријума по којима се може организовати стадијум ревизије који је интегрални процес писања.

\section{5. ЗАКљУЧАК}

Успешном организовању и вредновању наставе писменог изражавања потребан је интердисциплинаран приступ. У сродним дисциплинама: реторици, анализи дискурса и лингвистици текста пронаћи ћемо разрађен систем техника и поступака у прикупљању, одабирању, структурирању, уобличавању садржаја, али и критеријуме по којима текст 
стиче своју текстуалност и начине којима се остварује комуникативна намера и функција текста.

Пошто се писаном саставу приђе као тексту кога не карактерише само његова граматичка структура, већ се он јавља као вид комуникације са својом специфичном функцијом, наставников задатак би био да осмисли наставне активности (своје и ученичке), облике и методе које треба да примени, захтеве које треба да постави како би ученици остварили постигнућа која су, не само описана у законским регулативама, већ су и потреба савременог друштва.

Како бисмо унапредили наставу учења вештине писања неопходно је развијање адекватних стратегија писања које могу у великој мери ученицима обезбедити неопходна знања и развити способност да своје писмене саставе читају критички.

Развијање и подизање језичке културе на један виши ниво подразумева системски рад и на осталим елементима због којих се она нашла на незадовољавајућем нивоу, као што су: наставни планови и програми, број часова, приручници и уџбеници, али и однос друштва и појединаца према учењу матерњег језика.

\section{ЛИТЕРАТУРА}

Аристотел (1989). Реторика. Загреб: ИТП Напријед.

De Beaugrande, R., Dressler, W. U. (1981). Introduction to Textlinguisties. London: Longman.

Johnstone, B. (2004). "Discourse analysis and narrative", in Handbook of discourse analysis, eds. Deborah Schffrin, Deborah Tannen \& Heidi E. Hamilton (Malden: Blackwell Publisher): 635-649.

Brinker, K. (1985). Linguistische Textanalyse. Berlin: Erich Schmidt Verlag.

Брборић, В. (2004). Правопис српског језика у наставној пракси. Београд: Филолошки факултет.

Ћоровић, Д. (2008). ”Текст као интеракција: могуће импликације на наставу страних језика". Psihologia бр. 6: 77.

Драгићевић, Р. (2006). "Култура изражавања у настави српског језика". Иновачије у настави, XIX/1: 29-35.

Flower, L. i Hayes, J.R. (1981). "A cognitive process theory of writing". College Composition and Communication 32 (4): 365-387.

Глишић, Т., Илић, Ј. и др. (2013). Оиењивање засновано на компетенщијама у стручном образовању. Београд: Завод за унапређивање образовања и васпитања.

Halliday, M. A. K, Hasan, R. (1976). Cohesion in English. London: Longman. 
Јањић , М. (2008). Савремена настава говорне културе у основној школи. Нови Сад: Змај.

Јелачић Србуљ, В. (2005). Реторика и прогумнаГмата (припремне вежбе за беседнике): приручник за филолошке и класичне гимназије. Београд: Филолошка гимназија.

Mandler, J. M. (1983). "Some uses and abuses of a story grammar". Discourse Processes 6: 305-318.

Марковић, М. (1959). "Коришћење писмених састава за развијање језичко-стилског израза ученика". Настава и васпитање IV/1: 90-93.

Николић, М. (1983). Настава писмености. Београд: Научна књига.

Nikčević-Milković, A. (2008). "Procesni pristup pisanju kao oblikovanju teksta". Psihologijske teme 17, 1: 185-201.

Nikčević-Milković, A. (2010). "Kognitivni procesi pisanja kao oblikovanje teksta i kvaliteta pisanja teksta kod studenata”. Društvena istraživanja, 19, 4-5 (108109): 853-872.

Павловић, М. (1921). Настава српског језика у нашим средњим иколама, Просветни гласник Министарства просвете. Београд: Државна штампарија Краљевине Срба, Хрвата и Словенаца.

Павловић, Б, Шарић, А. (2012). ”Текстуална комуникација". Живот и школа бр. 28 (2): $32-44$.

Петровачки, Љ. (2008). Методичка истраживања у настави српског језика и књижевности. Нови Сад: Филозофски факултет.

Пешић Матијевић, Ј. (1997). "Анализа дискурса и њен однос са психологијом”. Психологија вол. 30, бр. 3 (1997): 263-278.

Росандић, Д. (1973). Методичке основе сувремене наставе хрватског или српског језика и књижевности у средњој школи. Загреб: Школска књига.

Rosenberg, V. M. (1989). Reading, Writing, Thinking. New York: Random House.

Салонски, С. (1959). "Значај вежбања за усвајање знања из правописа". Настава и васпитање IV/1: 190-195.

Стевановић, М. (2011). ”Правописне одлике језичке културе ученика у основној школи". Српски језик XVI/1-2: 637-652.

Стевановић, М. (1988). Теорија и пракса у настави усменог и писменог изражавања. Горњи Милановац: Дечје новине.

Шипка, М. (1959). ”О неписмености наших средњошколаца”. Језик VII/4: 118-121.

Van Dijk, T. A. (1988a). News Analysis. Hillsdale, NJ: Lawrence Erlbaum.

Van Dijk, T. A. (1988b). News as Discourse. Hillsdale, NJ: Lawrence Erlbaum.

Зељић, Г. (2004). "Језичка култура у образовању”. Педагогија LIX/1: 121-127.

Живковић, В. (2013). "Вештина писања есеја". Школски час српског језика и кьижевности бр. 2: 30-44. 
Tina Kaplarević

\title{
INTERDISCIPLINARY APPROACH TO WRITTEN ESSAYS IN TEACHING LANGUAGE CULTURE
}

\begin{abstract}
Summary
Due to the great importance of written expression in raising the level of language culture, in this paper the attention will be focused on interdisciplinary approaches to writing as a part of the most important and basic way in which these classes are carried out and assessed. Although teaching the culture of written expression has legally regulated goals, in practice it was observed that the existing methodological approaches do not contribute satisfactorily to their achievement. In teaching written expression the implementation of approaches used in rhetoric (the curriculum of secondary schools stipulates the implementation of essay writing only in the fourth grade, even though some basics are covered in earlier years), discourse analysis (it is based on narratives with their story grammar and text cohesion, which can then be applied to different types of texts that can be analyzed macrostructurally and microstructurally) and text linguistics (it relies on the seven standards of textuality: cohesion, coherence, intentionality, acceptability, informativity, situationality, intertextuality) could contribute to the training of students to understand and produce different types of texts in accordance with the needs of modern life and society.
\end{abstract}

Keywords: interdisciplinarity, methodical approaches, written composition, text.

Primljeno: 30.4.2017. Prihvaćeno: 12.11.2017. 